\title{
Effect of Potassium Nitrate on Yield and Yield Attributes of Spring Maize (Zea mays L.) under Different Dates of Planting
}

\author{
Harmeet Singh*, Mandeep Singh and Jasjit Singh Kang \\ Department of Agronomy, Punjab Agricultural University, Ludhiana-141004, India \\ *Corresponding author
}

\author{
A B S T R A C T
}

\section{Keywords \\ Spring maize, Heat stress, Dates of planting, Foliar application, $\mathrm{KNO}_{3}$. \\ Article Info \\ Accepted: 22 February 2017 Available Online: 10 March 2017}

A field experiment entitled was conducted on loamy sand soil, which was low in organic carbon and available nitrogen and medium in available phosphorus and potassium during spring season of 2014 and 2015 at Student's Research Farm, Punjab Agricultural University, Ludhiana. Experiment was laid out in split plot design with four replications with three dates of planting viz. February 10, February 20 and March 2 in main plots and seven foliar applications viz. $1 \% \mathrm{KNO}_{3}$ at tassel initiation, $2 \% \mathrm{KNO}_{3}$ at tassel initiation, $1 \% \mathrm{KNO}_{3}$ at tassel initiation+ another spray after one week, $2 \% \mathrm{KNO}_{3}$ at tassel initiation+ another spray after one week, WS at tassel initiation tassel initiation+ another spray after one week and control (no spray) in sub plots. Different planting dates as well as foliar applications of both water and $\mathrm{KNO}_{3}$ had a significant effect on yield and yield attributes of spring maize. The planting of maize on February 20 gave significantly higher grain yield. Various yield attributes (number of cobs per plant, cob length, cob girth, number of rows per cob, number of grains per row, number grains per cob and 100 grain weight) were higher for February 20. Foliar application had significant effect on various yield attributes like number of cobs per plant, cob length, cob girth, number of rows per cob, number of grains per row, number grains per cob and 100 grain weight with $1 \% \mathrm{KNO}_{3}$ at tassel initiation gave significantly higher grain yield.

\section{Introduction}

Maize (Zea mays L.) is one of the most important cereal crops in world because of its high yield potential. Among cereals, it occupies third place after rice and wheat on basis of both area and production in the world. In India, maize was cultivated on an area of 8.6 million hectare, production of 23.7 million tones and productivity $27.5 \mathrm{q} / \mathrm{ha}$ (Anonymous, 2014). Maize contains 70 percent carbohydrates and 10 percent quality proteins. India's share in total world maize production is about $2.26 \%$ and in year 2014 . India ranks sixth in maize production in the world with area 9.4 million hectares and annual production 23 million tonnes (USDA, 2014). Maize, being a $C_{4}$ plant is considered to be energy efficient and has high yield potential which also adds towards its importance in agriculture. The demand for maize grains is increasing all over the world due to their diversified usages such as food for human beings, feed for the animals and raw material for many industrial products. With introduction and development of new high yielding varieties and increased water resources and irrigation facilities, maize is 
grown year around in India (Singh and Singh, 2000). Maize is largely grown in north Indian states of Uttar Pradesh, Rajasthan, Madhya Pradesh, Bihar, Himachal Pradesh, Jammu and Kashmir and Punjab, which together account for two-third, of the total area and production of the crop. In south India, Karnataka and Andhra Pradesh states are the major producers of maize.

Date of sowing/planting is the basic and most important factor, which affects the crop growth and yield through its influence on phonological and morphological development. The crop sown under different sets of environmental conditions, which are likely to affect the plant growth and yield, generally, the spring maize is sown from mid January to mid February, but due to late harvesting of potato and non availability of labour in peak season, its sowing is often delayed to end February to early March. Sometimes due to prevailing low market prices, farmers prefer to delay digging of potato until they fetch high price which also delays its sowing. Due to prevalent low temperature during early February, there may be delayed emergence while in the crop sown late in March, the reproductive phase of crop coincides with the period of high temperature and might face stress at the anthesis causing desiccation of pollens resulting in poor grain filling in ears and reduced grain yield. Preliminary experiments have shown wide variations in yield of maize sown at different dates during spring season.

Temperature stresses (high and low temperature) are the major environmental factors affecting plant growth, development and also induce morphological, physiological and biochemical changes in plants. Recently, spray of osmoprotectants has been proposed to mitigate the effect of temperature and water stress (Yancey, 1994). The nutritional role of potassium in tolerance and avoidance of abiotic stress is universal. Application of potassium nitrate $\left(\mathrm{KNO}_{3}\right)$ may be considered as an option through its effect on water uptake, root growth, transpiration and stomatal behavior (Nelson 1980, Hsiao and Lauchli, 1986). Besides, crop growth can also be enhanced through nitrogen and potassium nutrition as $\mathrm{N}$ and $\mathrm{K}$ play a unique role in metabolic, physiological and biochemical functions of plants. Application of $\mathrm{KNO}_{3}$ at different doses may also have differential response in terms of growth and development of a crop

\section{Materials and Methods}

The experiment was conducted at the Student's Research Farm Punjab Agricultural University, Ludhiana, Punjab, India during the spring season for two years i.e. spring 2014 and 2015. The soil of experimental field was loamy sand, which was low in organic carbon and available nitrogen and medium in available phosphorus and potassium The trial was laid out in Split Plot Design (SPD) with four replications assigning 21treatment combinations of 3 sowing dates (February 10, February 20 and March 2) in main plots, six level of foliar application (water spray (WS) at tassel initiation, WS at tassel initiation stage + another spray after one week, $1 \%$ potassium nitrate $\left(\mathrm{KNO}_{3}\right)$ at tassel initiation, $1 \% \mathrm{KNO}_{3}$ at tassel initiation + another spray after one week, $2 \% \mathrm{KNO}_{3}$ at tassel initiation and $2 \% \mathrm{KNO}_{3}$ at tassel initiation + another spray after one week) and control (no spray) in sub plots. Hybrid PMH-1 variety of maize was sown according to the dates decided in the treatment, maintaining $60 \mathrm{~cm}$ row-to-row and $20 \mathrm{~cm}$ plant to plant distance with the seed rate of $25 \mathrm{~kg} \mathrm{ha}^{-1}$ at $2.5 \mathrm{~cm}$ depth with a fixed dose of nitrogen (125 kg/ha) and phosphorus (60 kg/ha). Data on various yield parameters (number of cobs per plant, number of rows per cob, number grains per row, number of grains per cob, 100-grain weight, 
cob girth and cob length) were collected using standard procedures. Grain and stover yield was also recorded. Experiment as data was analyzed in split plot (Cochran and Cox 1967) as per standard statistical procedure using CPCS1 software developed by the Department of Mathematics and Statistics, PAU, Ludhiana and adapted by Cheema and Singh (1991). LSD test at 5\% probability was used to compare the differences among treatments.

\section{Results and Discussion}

Effect of dates of plantings on yield and yield attributes

\section{Number of cobs per plant}

Number of cobs per plant decreased significantly with delay in planting. Maize crop planted on February 20 produced 1.2 cobs per plant, which were $20 \%$ more than March 2 planted crop (1.0) but statistically at par with February 10 planted crop (1.2) during both 2014 and 2015 year. This can be attributed to favourable environmental condition prevailing during early growth stages in February planted crop resulting in healthy development of all plants, leading to higher number of cobs. Same result was reported by Singh (2002) at Ludhiana the number of cobs per plant of march planted crop was significantly lesser than January planted crop.

\section{Cob length}

The highest cob length was recorded in February 20 planted crop which was $12.1 \%$ and $10.6 \%$ higher than March 2 planted crop in 2014 and 2015, respectively and statistically at par with February 10 planted crop. Singh (2011) at Ludhiana also made similar observations in spring maize and observed that January 17 planting resulted in significantly more cob length $(15.6 \%)$ than that under February 28 planting.

\section{Cob girth}

Cob girth decreased significantly with delay in planting from February to March. Comparatively thicker cobs $(15.8 \mathrm{~cm}, 16.6$ $\mathrm{cm})$ were produced in February 20 planted crop being $6.7 \%, 10.7 \%$ thicker than that of March $2(14.8 \mathrm{~cm}, 15.0 \mathrm{~cm})$ planted crop during 2014 and 2015, respectively but it was statistically at par with February 10 planted crop.

This could be because of longer grain filling period due to low temperature conditions and better utilization of light resulting in development of bold grains (Table 1). Singh (2011) at Ludhiana also made similar observations in spring maize and observed that January 17 planting resulted in significantly more cob girth $(14.2 \%)$ than that under February 28 planting. Singh (2002) also reported similar findings.

\section{Number of rows per cob}

The data on number of rows per cob presented in table 2 reveals that the number of rows per cob were significantly higher in February 20 planted crop which was statistically at par with February 10 planted crop during 2014 and 2015. Number of rows per cob was decreased significantly when planting was delayed from February 20 to March 2. February 20 planted crop recorded $10.3 \%, 14.8 \%$ higher number of rows per cob than March planted crop in 2014 and 2015, respectively. This might due to the favorable environmental conditions during the reproductive growth in February planted crop. The percent increase in number of rows per cob was 9.7 under $17^{\text {th }}$ January planting as compared to $28^{\text {th }}$ February planting was reported by Singh (2011). 


\section{Number of grains per row}

Number of grains per row is an important yield attribute that influences the number of grains per cob and finally affects the grain yield. The data on number of grains per row presented on table 2 reveals that a significant difference in number of rows per cob under different dates of plantings was observed. February 20 planted crop recorded significantly higher number of grains per row $(30.5,31.4)$, which were $21.5 \%$, and $22.2 \%$ higher than March 2 planted crop $(25.1,25.7)$ and statistically at par with February 10 planted crop (29.6, 30.4) in 2014 and 2015, respectively. This might be due to prolonged grain filling period due to favourable temperature in February 20 planted crop. Maryam et al., (2013) also observed that maximum number of grains per ear row (51.2) was observed for early sown crop and minimum value of 41 grains per ear row for later sown date.

\section{Number of grains per cob}

Number of grains per cob is an important yield attributes that influences the grain yield. Number of grains per cob are depends on number of grains per row and number rows per cob. It is the evident from data in table 2 that there was significant effect of planting dates on number of grains per cob. February 20 planted maize crop recorded significantly higher number of grains per cob (425.2, 440.9), which were $34 \%$ and $38.6 \%$ higher than March 2 in 2014 and 2015, respectively. It was statistically at par with February 10 planted crop in both years. This might be due to prolonged grain filling period due to favourable temperature in February 20 planted crop. Higher grain number in early plantings could be attributed to more size of source which was responsible for large size of sink and produced more size of cobs in terms of more length and girth and number of rows per cob. Singh (2005) also reported that significantly higher number of grains per cob (431.3) in January 29 planted crop, which were $11.4 \%$ higher than February 28 planted crop. In Brazil, Rizzardi et al., (1994) studied delay in sowing resulted in lower number of grains per cob.

\section{0- grain weight}

Grain weight is important yield attribute which is controlled both genetically and environmentally. The data presented in table 2 revealed that planting dates had significant effect on 100-grain weight which was decreased with delay in planting. 100-grain weight tended to decrease with delay in planting from February $10(26.8 \mathrm{~g}, 27.0 \mathrm{~g})$ and February 20 (27.8 g, $28.3 \mathrm{~g}$ ) to March 2 $(22.6 \mathrm{~g}, 22.8 \mathrm{~g})$ in 2014 and 2015, respectively. But both February plantings were statistically at par with each other. This might be because of long and thick cobs filled with bold grains produced during early planting dates having comparatively low temperature prevailing conditions during the extended grain filling period. A significant decrease of $17.5 \%$ in test weight was reported by Singh (2005) when planting was delayed by 30 days from January 29 .

\section{Grain yield}

The perusal of the data shown in table 3 revealed that different planting dates had a significant influence on the grain yield of maize hybrid PMH-1. Highest grain yield of $59.0 \mathrm{q} \mathrm{ha}^{-1}$ was recorded in February 20 planting which was $3.87 \%, 4.04 \%$ higher than February 10 and $68.6 \%, 55.8 \%$ higher than March 2 planting during 2014 and 2015, respectively. February 10 and February 20 plantings were at par with each other in respect of grain yield and both these dates were significantly better than March 2 . Increased grain yield in planting February 20 
and February 10 could be because of favourable effect of prevailing environmental conditions on various yield attributes. Significant increase in number of cobs per plant, cob length, cob girth (Table 1), number of grains per cob, number rows per cob, number of grains per row and 100-grain weight (Table 2) in the crop sown on February 10 and February 20 contributed towards increased total ear weight resulting in higher grain yield in these sowing dates. All these yield contributing attributes were favourably influenced because of favourable mean temperature of about $28.7{ }^{\circ} \mathrm{C}$ during the grain filling period of early planting as compared to later planting where it rose to $33.2^{0}$ C. Singh and Singh (2000) obtained $49.3 \%$ higher grain yield during early summer (6 February) than late summer (April 25). Singh (2011) at Ludhiana, who reported that crop sown on 17 January had significantly higher grain yield than late planting 28 February during spring season.

\section{Stover yield}

Data shown in table 2 revealed that yield of maize hybrid PMH-1 was significantly influenced by different planting dates. February 20 planted crop recorded highest dry stover weight of 147.0, $153.2 \mathrm{q} \mathrm{ha}^{-1}$, which were $1.4,1.9 \%$ higher than February 10 (145.0, 150.2 $\left.\mathrm{q} \mathrm{ha}^{-1}\right)$ and 21.5, 23.9\% higher than March 2 (121.0, $\left.123.6 \mathrm{q} \mathrm{ha}^{-1}\right)$ planted crop during 2014 and 2015, respectively. February 10 and February 20 plantings were statistically at par with each other in respect of stover yield and both these dates were significantly better than March 2 planting. This might be due more plant height and higher dry biomass due to longer span of growth from sowing to maturity in early planting. The results are in conformity with the results recorded by Singh (2002) who reported $20.2 \mathrm{q} \mathrm{ha}^{-1}$ decreases in stover yield with delay in planting from January to March for spring planted maize. Singh (2011) also reported a decrease in stover yield with delay in plantings of spring maize from January 17 to February 28.

\section{Foliar applications}

\section{Cob length}

Among the foliar applications $1 \%$ potassium nitrate application at tassel initiation produced significantly longer cobs (19.4, $20.6 \mathrm{~cm})$ which were $8.4,15.1 \%$ higher than control (no spray), 7.8, 6.7\% longer than WS at tassel initiation and 7.2, $7.8 \%$ longer than WS at tassel initiation + another spray after one week during 2014 and 2015, respectively and statistically at par with rest of foliar applications (Table 1). Serpa et al., (1984) also reported that cob length was significantly increased with application of potassium.

\section{Cob girth}

The cob girth increased progressively with the foliar applications of either water or $\mathrm{KNO}_{3}$. Plants sprayed with $1 \%$ potassium nitrate at tassel initiation produced significantly thicker cobs $(15.9,16.5 \mathrm{~cm})$, which were $6.7,7.1 \%$ thicker than control (no spray), 5.3, 7.1\% thicker than WS at tassel initiation and 4.6, $6.4 \%$ thicker than WS at tassel initiation + another spray after one week during 2014 and 2015 , respectively and statistically at par with foliar application of $1 \%$ potassium nitrate at tassel initiation + another spray after one week, $2 \%$ potassium nitrate at tassel initiation and $2 \%$ potassium nitrate at tassel initiation + another spray after one week (Table 1). This might be due tendency of potassium and nitrogen in accelerating growth, photosynthetic activity and efficient translocation of photosynthates. 
Table.1 Effect of dates of planting and foliar application of $\mathrm{KNO}_{3}$ on yield attributes of spring maize

\begin{tabular}{|c|c|c|c|c|c|c|c|c|c|c|}
\hline \multirow[t]{2}{*}{ Treatments } & \multicolumn{2}{|c|}{$\begin{array}{l}\text { Number of cobs } \\
\text { plant }^{-1}\end{array}$} & \multicolumn{2}{|c|}{$\begin{array}{l}\text { Cob length } \\
(\mathrm{cm})\end{array}$} & \multicolumn{2}{|c|}{$\begin{array}{l}\text { Cob girth } \\
\text { (cm) }\end{array}$} & \multicolumn{2}{|c|}{$\begin{array}{l}\text { Number of } \\
\text { rows cob }\end{array}$} & \multicolumn{2}{|c|}{$\begin{array}{l}\text { Number of } \\
\text { grains row }^{-1}\end{array}$} \\
\hline & 2014 & 2015 & 2014 & 2014 & 2014 & 2015 & 2014 & 2015 & 2014 & 2015 \\
\hline \multicolumn{11}{|l|}{ Dates of planting } \\
\hline 10 February & 1.2 & 1.2 & 19.1 & 20.4 & 15.7 & 16.2 & 13.6 & 13.7 & 29.6 & 30.4 \\
\hline 20 February & 1.2 & 1.3 & 19.5 & 20.9 & 15.8 & 16.6 & 13.9 & 14.0 & 30.5 & 31.4 \\
\hline 2 March & 1.0 & 1.0 & 17.4 & 18.9 & 14.8 & 15.0 & 12.6 & 12.2 & 25.1 & 25.7 \\
\hline $\operatorname{LSD}(\mathrm{p}=0.05)$ & 0.1 & 0.1 & 0.8 & 0.7 & 0.5 & 0.7 & 0.6 & 0.6 & 3.0 & 2.8 \\
\hline \multicolumn{11}{|l|}{ Foliar applications } \\
\hline $1.0 \% \mathrm{KNO}_{3}$ spray at Tassel Initiation (TI) & 1.1 & 1.2 & 19.4 & 20.6 & 15.9 & 16.5 & 14.2 & 14.4 & 31.2 & 31.8 \\
\hline $1.0 \% \mathrm{KNO}_{3}$ spray at TI +another spray after one week & 1.2 & 1.1 & 19.2 & 20.3 & 15.7 & 16.3 & 14.0 & 14.1 & 30.2 & 31.1 \\
\hline $2.0 \% \mathrm{KNO}_{3}$ spray at TI & 1.1 & 1.2 & 19.0 & 20.1 & 15.6 & 16.3 & 13.9 & 14.1 & 30.2 & 30.8 \\
\hline $2.0 \% \mathrm{KNO}_{3}$ spray at TI +another spray after one week & 1.2 & 1.2 & 19.0 & 20.2 & 15.7 & 16.2 & 14.1 & 14.2 & 30.3 & 30.9 \\
\hline Water spray at TI & 1.1 & 1.0 & 18.0 & 19.3 & 15.1 & 15.4 & 12.1 & 12.3 & 25.3 & 26.6 \\
\hline Water spray at TI + another spray after one week, & 1.2 & 1.2 & 18.1 & 19.1 & 15.2 & 15.5 & 13.0 & 12.9 & 25.9 & 27.6 \\
\hline Control (No spray) & 1.1 & 1.2 & 17.9 & 18.8 & 14.9 & 15.4 & 12.2 & 12.3 & 24.6 & 25.5 \\
\hline $\operatorname{LSD}(p=0.05)$ & NS & NS & 0.8 & 0.5 & 0.4 & 0.6 & 0.6 & 0.5 & 2.0 & 1.9 \\
\hline $\operatorname{LSD}(p=0.05)$ for interactions & \multicolumn{10}{|c|}{ NS } \\
\hline
\end{tabular}


Table.2 Effect of dates of planting and foliar application of $\mathrm{KNO}_{3}$ on number of grains per cob, 100-grain weight and grain and stover yield ( $\mathrm{q} \mathrm{ha}^{-1}$ ) of spring maize

\begin{tabular}{|c|c|c|c|c|c|c|c|c|}
\hline \multirow[t]{2}{*}{ Treatments } & \multicolumn{2}{|c|}{$\begin{array}{l}\text { No. of grains } \\
\text { cob }^{-1}\end{array}$} & \multicolumn{2}{|c|}{$\begin{array}{c}\text { 100-Grain } \\
\text { weight }\end{array}$} & \multicolumn{2}{|c|}{$\begin{array}{c}\text { Grain Yield } \\
\left(\mathrm{q} \text { ha }^{-1}\right)\end{array}$} & \multicolumn{2}{|c|}{$\begin{array}{c}\text { Stover Yield } \\
\left(\mathbf{q} \mathbf{h a}^{-1}\right)\end{array}$} \\
\hline & 2014 & 2015 & 2014 & 2015 & 2014 & 2015 & 2014 & 2015 \\
\hline \multicolumn{9}{|l|}{ Dates of planting } \\
\hline 10 February & 405.0 & 419.8 & 26.8 & 27.0 & 56.8 & 59.3 & 145.0 & 150.2 \\
\hline 20 February & 425.2 & 440.9 & 27.8 & 28.3 & 59.0 & 61.7 & 147.0 & 153.2 \\
\hline 2 March & 315.9 & 318.1 & 22.6 & 22.8 & 35.0 & 39.6 & 121.0 & 123.6 \\
\hline $\operatorname{LSD}(p=0.05)$ & 37.0 & 41.2 & 1.6 & 2.1 & 5.1 & 4.4 & 5.4 & 6.4 \\
\hline \multicolumn{9}{|l|}{ Foliar applications } \\
\hline $1.0 \% \mathrm{KNO}_{3}$ spray at tassel initiation $(\mathrm{TI})$ & 445.8 & 461.4 & 28.3 & 28.4 & 55.8 & 58.7 & 148.0 & 155.5 \\
\hline $1.0 \% \mathrm{KNO}_{3}$ spray at $\mathrm{TI}+$ another spray after one week & 425.0 & 438.5 & 27.3 & 27.3 & 53.9 & 56.9 & 142.0 & 149.8 \\
\hline $2.0 \% \mathrm{KNO}_{3}$ spray at $\mathrm{TI}$ & 421.7 & 434.8 & 27.0 & 27.6 & 54.1 & 56.8 & 142.0 & 151.1 \\
\hline $2.0 \% \mathrm{KNO}_{3}$ spray at $\mathrm{TI}+$ another spray after one week & 428.7 & 439.2 & 28.0 & 27.5 & 53.9 & 56.8 & 143.0 & 152.4 \\
\hline Water spray at TI & 307.5 & 320.7 & 23.4 & 23.7 & 46.9 & 48.3 & 123.0 & 124.5 \\
\hline Water spray at $\mathrm{TI}+$ another spray after one week, & 339.5 & 356.6 & 24.5 & 24.2 & 49.0 & 50.1 & 127.0 & 126.5 \\
\hline Control (No spray) & 300.0 & 308.5 & 21.8 & 21.6 & 44.1 & 44.8 & 120.0 & 122.0 \\
\hline $\operatorname{LSD}(p=0.05)$ & 27.0 & 27.7 & 1.6 & 1.6 & 2.5 & 2.3 & 13.5 & 11.3 \\
\hline $\operatorname{LSD}(p=0.05)$ for interactions & \multicolumn{8}{|c|}{ NS } \\
\hline
\end{tabular}




\section{Number of rows per cob}

Number of rows per cob was significantly influenced with foliar applications of both water and $\mathrm{KNO}_{3}$. Foliar application of $1 \%$ potassium nitrate at tassel initiation resulted in more number of rows per cob $(14.2,14.4)$ which was significantly more than control (no spray) $(12.2,12.3)$, WS at tassel initiation $(12.1,12.3)$ and WS at tassel initiation + another spray after one week $(13.0,13.1)$ during 2014 and 2015, respectively but statistically at par with foliar application of $1 \%$ potassium nitrate at tassel initiation + another spray after one week, $2 \%$ potassium nitrate at tassel initiation and $2 \%$ potassium nitrate at tassel initiation + another spray after one week (Table 2). This might be due tendency of potassium and nitrogen in accelerating growth, photosynthetic activity and efficient translocation of photosynthates.

\section{Number of grains per row}

Among the foliar application treatments 1\% potassium nitrate at tassel initiation stage significantly increased the number grains per row $(31.2,31.8)$, which were $26.8,24.7 \%$ more than control (no spray, 23.3, 19.5\% more than WS at tassel initiation and 20.4, $15.2 \%$ more than WS spray at tassel initiation + another spray after one week during 2014 and 2015, respectively while rest of the applications were statistically at par with $1 \%$ potassium nitrate application. This might be due enhanced photosynthetic activity and translocation of photosynthates by potassium and nitrate.

\section{Number grains per cob}

Foliar applications also had significant effect on the number of grains per cob. The crop treated with $1 \%$ potassium nitrate produced more number of grains per cob $(445.8,461.5)$ which statistically at par with foliar application of $1 \%$ potassium nitrate at tassel initiation + another spray after one week $(425.0,438.5), 2 \%$ potassium nitrate at tassel initiation $(421.7,434.8)$ and $2 \%$ potassium nitrate at tassel initiation + another spray after one week $(428.7,439.2)$ but significantly higher than control (no spray), WS at tassel initiation and WS at tassel initiation at tassel initiation + another spray after one week during 2014 and 2015, respectively. It might be due to more size of source which was responsible for large size of sink under foliar applications of 1 and $2 \% \mathrm{KNO}_{3}$. Shah (1984) also observed that number of grains per cob was significantly increased by application of potassium.

\section{0 - Grain weight}

Among the foliar application 1\% potassium nitrate at tassel initiation stage significantly increased 100-grain weight $(28.3,28.4 \mathrm{~g})$, which were $29.8,31.5 \%$ more than control (no spray), 21.0, 19.8\% more than WS at tassel initiation and 16,17.4\% more than WS spray at tassel initiation + another spray after one week during 2014 and 2015, respectively. Rest of the treatments was statistically at par with $1 \%$ potassium nitrate application. This might be due enhanced photosynthetic activity and translocation of photosynthates by potassium and nitrate.

\section{Grain yield}

Grain yield is a function of yield attributes, which were favorably influenced by foliar applications. Different levels of potassium nitrate foliar application (1 and 2\%) significantly influenced the grain yield. Foliar application with $1 \%$ potassium nitrate at tassel initiation stage resulted in significantly higher grain yield $\left(55.8,58.7 \mathrm{q} \mathrm{ha}^{-1}\right)$ which was $26.5,31.0 \%$ more than control (no spray), $18.9,21.5 \%$ more than water spray at tassel initiation and 13.8, 17.2\% more than that 
obtained with water spray at tassel initiation + another spray after one week during 2014 and 2015, respectively. But it was statistically at par with foliar application of $1 \%$ potassium nitrate at tassel initiation + another spray after one week, $2 \%$ potassium nitrate at tassel initiation and $2 \%$ potassium nitrate at tassel initiation + another spray after one week with application of $1 \%$ potassium nitrate at tassel initiation.

Significantly increased cob length, cob girth, number rows per cob, number of grains per row, number of grains per cob and 100-grain weight (Tables 1 and 2) might have resulted in increased grain yield. Suwanarit and Sestapukdee (1989) conducted a pot experiment with six treatments viz. control (no foliar), 1 per cent $\mathrm{KCl}, 1.4$ per cent $\mathrm{KNO}_{3}, 1.2$ per cent $\mathrm{K}_{2} \mathrm{SO}_{4}, 1.8$ per cent $\mathrm{KH}_{2} \mathrm{PO}_{4}$ and 1.2 per cent $\mathrm{K}_{2} \mathrm{HPO}_{4}$ and sprays were applied on the third day after 50 per cent tasselling $(50 \%$ of tassels, male flowers, visible). Results showed that only the potassium nitrate spray caused a statistically significant increase in grain yield of 47 per cent compared to the control. Ali et al (2004) also reported that grain yield of spring maize increased by potassium application.

\section{Stover yield}

Different foliar application of both water and $\mathrm{KNO}_{3}$ at different stages had a pronounced effect on the stover yield of maize crop. Different levels of potassium nitrate foliar application (1\% and 2\%) significantly influenced the grain yield. Foliar application with $1 \%$ potassium nitrate at tassel initiation stage resulted in significantly higher stover yield $\left(148.0,155.5 \mathrm{q} \mathrm{ha}^{-1}\right)$ which was 23.3, $27.4 \%$ more than control (no spray), 20.3, $24.9 \%$ more than water spray at tassel initiation and $16.5,22.9 \%$ more than that obtained with water spray at tassel initiation + another spray after one week during 2014 and
2015, respectively. But, this treatment was statistically at par with foliar application of $1 \%$ potassium nitrate at tassel initiation + another spray after one week, 2 per cent potassium nitrate at tassel initiation and $2 \%$ potassium nitrate at tassel initiation + another spray after one week with application of $1 \%$ potassium nitrate at tassel initiation. Significantly increased plant height and dry biomass production and leaf area index might have resulted in increased stover yield. Ali et al., (2004) also reported that biological yield of spring maize increased by potassium application.

From the study of 2014 and 2015, it is concluded that both date of planting and foliar application had significant effect on yield attributes and yield of spring maize. Planting of spring maize at 20 February and $1 \% \mathrm{KNO}_{3}$ at tassel initiation resulted higher yield attributes and yield.

\section{References}

Ali, T., Anwar, S., Shah, W.A. and Ahmad, B. 2004. Response of maize hybrids/cultivars to various levels of potassium and irrigation frequencies. $J$. Agron., 3: 201-207.

Anonymous. 2013. Area and production of maize in India and world. http//www.factfish.com

Anonymous. 2015. Package of practices for kharif crops. Pp. 19. Punjab Agricultural University, Ludhiana, India.

Cheema, H.S. and Singh, B. 1991. Software statistical package CPCS-1. Department of Statistics, Punjab Agriculture University, Ludhiana, India.

Cochran, W.C. and Cox, G.M. 1967. Experimental Design, Asia Publishing House, Bombay.

Hsiao, T.C. and Lauchli, A. 1986. Role of potassium in plant water relations In 
Tinder, B and Lauchli, A (ed.). Adv. Pl. Nut., 2: 281-312, Prager, New York.

Maryam, J., Darabi, F., Naseri, R., Naserirad, H. and Bazdar, S. 2013. Effect of Planting Date and Nitrogen Fertilizer Application on Grain Yield and Yield Components in Maize (SC 704). AmEuras. J. Agric. Environ. Sci., 13(7): 914-19.

Nelson, W.L. 1980. Interaction of potassium with moisture and temperature In: Nelson W L (ed.) Potassium in Agriculture, pp. 109-12. Potash and Phosphate Inst., Atlanta, USA.

Rizzardi, M.A., Witeck, D. and Deggerone, I. 1994. Grain yield and yield components of maize cultivars at two sowing dates. Ciencia Rural, 24(3): 477-82.

Serpa, J.E.S., de Carvalho, H.W.L. and Siquira, L.A. 1984. Study on the behavior of maize cultivars in semi arid region of the state of Sergipe. Comunicado Tecnico, UEPAE de Aracaju 16: 7.

Shah, S.N.H. 1984. Effect of planting pattern and fertilizer application on the growth and yield of maize. M.Sc (Hons.) Agriculture Thesis, Department of Agronomy, University of Agriculture Faisalabad, Pakistan.

Singh, S. and Singh, T.N. 2000. Response of maize crop to early and late summer sowing conditions. Indian J. Plant Physiol., 5: 307-313.
Singh, Y. 2002. Influence of sowing dates, spacing and varieties on growth and yield of spring planted maize (Zea mays L.). M. Sc. Thesis, Department of Agronomy, Punjab Agricultural University, Ludhiana, India.

Singh, K. 2005. Performance of spring planted maize in relation to planting dates, methods of sowing and nitrogen levels, M.Sc. Thesis, Department of Agronomy, Punjab Agricultural University, Ludhiana, India.

Singh, M. 2011. Growth, yield and water productivity of spring planted hybrid maize (Zea mays L.) cultivars as influenced by method and time of planting and irrigation regimes, Ph.D. Dissertation, Punjab Agricultural University, Ludhiana, India.

Suwanarit, A. and Sestapukdee, M. 1989. Stimulating effects of foliar K-fertilizer applied at the appropriate stage of development of maize: A new way to increase yield and improve quality. Plant and soil, 120(1): 111-124.

USDA. $2014 . \quad$ http://apps.fas.usda. gov/posdonline/circulars/production.pdf

Waraich, E.A., Ahmad, A., Halim, A. and Aziz, T. 2012. Alleviation of temperature stress by nutrient management in crop plants: a review. $J$. Soil Sci. Plant Nutr., 12(2): 221-244.

\section{How to cite this article:}

Harmeet Singh, Mandeep Singh and Jasjit Singh Kang. 2017. Effect of Potassium Nitrate on Yield and Yield Attributes of Spring Maize (Zea mays L.) under Different Dates of Planting. Int.J.Curr.Microbiol.App.Sci. 6(3): 1581-1590. doi: https://doi.org/10.20546/ijcmas.2017.603.182 